\title{
PREVALENCE OF MULTIDRUG-RESISTANT BACTERIAL COLONIZATION AND RISK FACTORS IN GERIATRIC NURSING HOME RESIDENTS
}

Turkish Journal of Geriatrics DOI:10.31086tjgeri.2018137965 2018:21 (1):41-48

- Oya Özlem EREN KUTSOYLU1

- Vildan AVKAN OĞUZ

- Madina ABDULLAYEVA'

- Nil TEKIN ${ }^{2}$

- Nur YAPAR 1
CORRESPONDANCE

Vildan AVKAN OĞUZ

Dokuz Eylül University, Faculty of Medicine Izmir, Turkey

Phone: 02324124306

e-mail: vildan.oguz@gmail.com

Received: $03 / 01 / 2018$

Accepted: $28 / 02 / 2018$

Dokuz Eylül University, Faculty of Medicine Izmir, Turkey

Narlidere Geriatric Care Center and

Residential Home

Izmir, Turkey

This study was presented in English in IDWEEK 2017 and for KLiMiK 2017 congress in Turkish.

\section{Abstract}

Introduction: Aim of this study is to determine the frequency of nasal, axillary and rectal colonization by multidrug-resistant bacteria and the risk factors for colonization in nursing home residents.

Materials and Method: In this cross-sectional study, demographic data and risk factors of the residents were recorded. Data regarding patients' independence were collected using activities of daily living form. Nasal and axillary swabs were analyzed for methicillin-resistant Staphylococcus aureus and rectal swabs for vancomycin-resistant enterococci, extendedspectrum beta-lactamase-producing Enterobacteriaceae, and carbapenemase-producing Klebsiella pneumoniae.

Results: From 247 residents, 247 axillary, 246 nasal, and 245 rectal swabs were obtained. Median age was $85 \pm 6.7$ and 190 (77\%) residents were female. Swab samples from 75 (30\%) residents yielded S. aureus, $8(3.2 \%)$ of which were methicillin-resistant. Of the residents, 10 (4.1\%) vancomycin-resistant enterococci, 17 (6.9\%) extended-spectrum beta-lactamase-producing Enterobacteriaceae, one (0.4\%) carbapenemase-producing K. pneumoniae were found. Colonization with more than one type of multidrug-resistant bacteria was found in 3 (1.2\%) residents. Colonization rates of multidrug-resistant bacteria were 2.7 times higher with antibiotic use in the last month and 3.1 times with immobility and enteral support. Colonization rate of multidrug-resistant bacteria increased with higher activities of daily living scores $(p=0.004)$.

Conclusion: The prevalence of multidrug-resistant bacterial colonization was $12.9 \%$ and the risk factors have been changed according to bacterial species. Colonization rate increased with greater dependence in activities of daily living. In nursing homes, for management of multidrug-resistant bacterial infections, risk factors for colonization and surveillance analysis should be considered.

Keywords: Nursing homes; Drug Resistance, Multiple; Methicillin-Resistant Staphylococcus
ARASTTIRMA

\section{YAŞLI BAKIMEVI SAKINLERINDE ÇOK ILACA DIRENÇLI BAKTERI KOLONIZASYONUNUN PREVALANSI VE RISK FAKTÖRLERI}

\section{$\ddot{O}_{z}$}

Giriş: Bu çalışmanın amacı yaşlı bakım evi sakinlerinde çok ilaca dirençli bakterilerle nazal, aksiller ve rektal kolonizasyon sıklığını ve kolonizasyon risk faktörlerini saptamaktır.

Gereç ve Yöntem: Kesitsel çalışmada, sakinlerin demografik özellikleri ve risk faktörleri kaydedildi. Sakinlerin fonksiyonel bağımlılığı ile ilişkili veriler, günlük yaşam formunun genel ve enstrümental aktiviteleri birlikte kullanılarak toplandı. Nazal ve aksiller sürüntülerde metisiline dirençli Staphylococcus aureus kolonizasyonu, rektal sürüntüde vankomisin dirençli enterokok, genişletilmiş spektrumlu beta laktamaz salgılayan Enterobacteriaceae, karbapenemaz üreten Klebsiella pneumoniae kolonizasyonu araştırıldı.

Bulgular: Çalışmaya katılan 247 sakinden 247 aksiller, 246 nazal, 245 rektal sürüntü örneği alındı. Medyan yaş $85 \pm 6.7$ olup, 190 (\%77) sakin kadındı. 75 (\%30) sakinde S. aureus ve bunların 8'inde (\%3.2) metisiline direnç belirlendi. Sakinlerin 10 (\%4.1)'unda vankomisine dirençli enterokok, 17'sinde (\%6.9) genişletilmiş spektrumlu beta laktamaz salgılayan Enterobacteriaceae, birisinde (\%0.4) karbapenemaz üreten K. pneumonia saptandı. Üç (\%1.2) sakinde birden fazla çok ilaca dirençli bakteri ile kolonizasyon bulundu. Kolonizasyon risk faktörleri bakteri türüne göre değişmektedir. Çok ilaca dirençli bakteri ile kolonizasyon oranı son bir ayda antibiyotik kullanımı ile 2.7 kat, immobilite ve enteral destek ile 3.1 kat artmaktadır. Çok ilaca dirençli bakteri kolonizasyon oranı günlük yaşam aktivite skoru arttıkça artar $(p=0.004)$.

Sonuç: Bu çalışmada çok ilaca dirençli bakteri kolonizasyon yüzdesi $12.9^{\prime}$ 'dur ve risk faktörleri bakteri türüne göre değişir. Kolonizasyon oranı günlük yaşam aktivitelerinde bağımlılık arttıkça artmaktadır. Bu nedenle yaşlı bakım evlerinde çok ilaca dirençli bakteri infeksiyonlarını yönetmek için risk faktörleri ve surveyans analizleri göz önünde bulundurulmalıdır.

Anahtar sözcükler: Yaşıı bakım evi; Çok Illaca Direnç, MRSA, Vankomisin Dirençli Enterokok, Türkiye, Risk faktörleri 


\section{INTRODUCTION}

Infections caused by multidrug-resistant (MDR) bacteria are major healthcare concerns worldwide (1). Geriatric long-term care facilities in particular are considered reservoirs of MDR bacteria because they serve patients who are unable to perform activities of daily living and require frequent hospitalization. Colonization by these bacteria lays the foundation for resistant bacterial infections $(2,3)$. Infections caused by these microorganisms result in high mortality rates independent of age and increase the length of hospital stays and therefore medical costs (4). In long-term care residents, MDR bacterial infections are more difficult to manage and show poorer response to treatment because of the presence of underlying chronic diseases $(5,6)$. Therefore, the present study aimed to determine the prevalence of MDR bacterial colonization in geriatric patients and the risk factors that promote colonization in this age group.

\section{METHODS}

\section{Ethics statement}

Approval for this study was obtained from the Dokuz Eylül University (DEU) Non-invasive Research Ethics Committee (Approval Date:19/06/2014, No:2014/22-21). The study was supported under the scope of DEU Scientific Research Projects.

\section{Study design}

This cross-sectional study included individuals aged 65 years of age and older, residing at the Nursing Home unit of the Narlidere Elderly Care and Rehabilitation Center. This center has the highest capacity for elderly care in Turkey with 269 geriatric nursing home residents and a total of 1040 residents including those in the assisted living units; each room has a maximum of two occupants. The Nursing Home unit provides long-term care mainly for dependent elderly people with chronic illnesses. Residents of this nursing home include retired civil service workers and their relatives. Therefore, the average education and socioeconomic level of these residents is middle to high.

All the nursing home residents included in the study or their relatives signed an informed consent form. Residents in this unit stay in single-or doubleoccupancy rooms. The data of all consenting participants were recorded using data collection forms which included demographic data regarding age, gender, height, weight, immobility (activities of daily living score), and information regarding comorbidities, urinary/vascular catheterization, feeding method [enteral, parenteral, and/or percutaneous endoscopic gastrostomy (PEG)], presence of skin lesions including bed sores, history of hospitalization in the last three months, and use of antibiotics in the last month. A single form assessing both the activities of daily living scale and instrumental activities of daily living was used. Therefore, we used the Katz Index of Activities of Daily Living, which is designed to evaluate self-care functions in patients with chronic disease and elderly populations, and the Lawton Instrumental Activities of Daily Living Scale, which is designed to assess the performance of the elderly on activities of daily living $(7,8)$. Based on this form, the total activities of daily living ( $A D L$ ) scores ranged from 1 to 36, with higher scores indicating greater dependence. Scores of 1-19 were considered independent, 2029 as partially dependent, and scores of $30-36$ as totally dependent.

\section{Bacterial identification}

In order to evaluate colonization in the elderly nursing home residents, nasal, axillary, and rectal swab samples were obtained using sterile cotton swabs. The nasal and axillary swab samples were cultured using CHROMagar ${ }^{\mathrm{TM}}$ Staph aureus agar (Liofilchem ${ }^{\circledR}$ Staph aureus, Italy) and 5\% sheep blood agar (RTA, Turkey) to evaluate Staphylococcus aureus colonization. Rectal swabs were inoculated at bedside into eosin-methylene blue (EMB) agar (RTA, Turkey) and CHROMagar ${ }^{\mathrm{TM}}$ 
Enterobacteriaceae agar (Liofilchem ${ }^{\circledR}$ Chromatic CRE, Italy) to evaluate colonization with Enterobacteriaceae producing extended-spectrum beta lactamase (ESBL) and/or carbapenemase and were inoculated into enterococcosel liquid medium with vancomycin (RTA, Turkey) and 5\% sheep blood agar in order to detect colonization by vancomycin-resistant enterococci VRE). The cultures were incubated for $18-24 \mathrm{~h}$ at $35^{\circ} \mathrm{C}$. As per the Clinical and Laboratory Standards Institute (CLSI) recommendations, bacterial identification was performed using traditional methods based on the Gram nature of the isolates (9). API (BD BBL Crystal $^{\text {TM }}$ Gram-Positive ID System, USA) was used for the identification of VRE.

\section{Susceptibility tests}

Antibiotic susceptibility tests were performed according to CLSI recommendations using MuellerHinton agar (RTA, Turkey) using the Kirby-Bauer disc diffusion method. Oxacillin susceptibility of the isolated $S$. aureus colonies was determined using a cefoxitin disc $(30 \mathrm{mcg})$. Minimum inhibitor concentration (MIC) was determined using the vancomycin Etest (Liofilchem ${ }^{\circledR}$ MTS VANCOMYCIN, Italy).

Antimicrobial susceptibility of the Escherichiae coli and Klebsiella strains isolated from the Enterobacteriaceae family was assessed using ampicillin (10 mcg), amoxycillin/clavulanic acid (20/10 mcg), cefotaxime (30 mcg), ceftazidime (30 mcg), cefoxitin (30 mcg), ertapenem (10 mcg), and ceftazidime/clavulanic acid (30/10 mcg) discs. The presence of ESBL in resistant gramnegative strains was determined using cefotaxime/ ceftazidime+clavulanic acid Etest (Liofilchem $®$ s.r.l. $4 \mathrm{mg} / \mathrm{L}$ ) and double disc synergy test. To determine carbapenem resistance, rectal swab samples were incubated in brain heart infusion broth, then analyzed using Chromogenic KPC (Biolife, Ref CHR174 Lot: 174206) medium and ertapenem (10 mcg) disc.

\section{Statistical analysis}

Statistical analysis was performed using SPSS 15.0 software. The participants were classified into groups with and without colonization, and statistical comparisons between the two groups were made using the chi-square test for a two-way table, Fisher's exact test, and independent samples t-test. Multivariate backward logistic regression analyses were used to identify independent risk factors for MDR bacteria.

\section{RESULTS}

During the study period, 247 (91.8\%) residents were present in the nursing home with 269 beds, and all of them were included. In total, 247 axillary, 246 nasal, and 245 rectal swab samples were obtained from the 247 elderly nursing home residents who participated in the study. A nasal swab could not be obtained from one participant because of history of nasal fracture surgery, and two participants chose not to give rectal swab samples.

Risk factors: Of the 247 nursing home residents, 190 (77\%) were females and the average age was $85 \pm 6.7(67-103)$ years. The median duration of residence for each resident in the nursing home was $6.66 \pm 4.57$ years ( 14 days -14.58 years). Only 5 (2.0\%) of the residents had no underlying chronic disease. Alzheimer's disease or dementia associated with other causes was present in 160 (64.5\%) of the nursing home residents. The total ADL score was above 30 for 125 (51.0\%) residents, and 84 (33.9\%) were immobile. Of the immobile residents, 57 (67.8\%) had dementia. Thirty-two (12.9\%) of the residents had taken antibiotics in the last month and 11 (4.4\%) had been hospitalized in the last 3 months. Eight (3.23\%) of the residents had bedsores, 31 (12.6\%) were receiving enteral nutrition support, and 7 (2.8\%) were being fed via PEG. Only one $(0.4 \%)$ patient had a urinary catheter and one $(0.4 \%)$ had a vascular catheter. The risk factor analyses for patients with and without colonization are shown in Table 1. Antibiotic use in the last month, 
malignancy, immobility, enteral supplementation, and PEG were statistically significant risk factors in univariate analysis of residents with colonization by any MDR bacteria. Multivariate logistic regression analysis of independent risk factors for MDR bacteria is shown in Table 2. Twenty-nine
(90.6\%) of the colonized patients had lived in the nursing home unit for more than one year. The colonization rate increased as ADL scores (i.e. dependence) increased ( $p=0.004$ ). ADL scores and immobility of residents colonized with MDR bacteria are presented in Table 3.

Table 1. Presence of risk factors for MDR bacteria.

\begin{tabular}{|c|c|c|c|c|c|c|}
\hline Risk factors & $\begin{array}{c}\text { Colonized } \\
\text { with MDR } \\
n=32(\%)^{*}\end{array}$ & $p$ value & $\begin{array}{r}\text { Colonized } \\
\text { with gram } \\
\text { negative MDR } \\
n=17(\%)\end{array}$ & $p$ value & $\begin{array}{r}\text { Colonized } \\
\text { with gram } \\
\text { positive MDR } \\
n=18(\%)\end{array}$ & $\mathrm{p}$ value \\
\hline Antibiotic use (Last month) & $9(28.1)$ & 0.006 & $6(35.2)$ & 0.004 & $4(22.2)$ & 0.265 \\
\hline Skin lesions & $2(6.3)$ & 0.619 & $1(5.8)$ & 0.442 & $1(5.5)$ & 0.459 \\
\hline $\begin{array}{l}\text { Hospitalization in the last } 3 \\
\text { months }\end{array}$ & $3(9.4)$ & 0.323 & $3(17.6)$ & 0.032 & $0(0.0)$ & - \\
\hline Malignancy & $5(15.6)$ & 0.024 & $2(11.2)$ & 0.306 & $3(16.6)$ & 0.099 \\
\hline $\begin{array}{l}\text { Dementia/Alzheimer's } \\
\text { disease }\end{array}$ & $25(78.1)$ & 0.082 & $14(82.3)$ & 0.118 & $14(77.7)$ & 0.244 \\
\hline Immobility & 19 (59.4) & 0.001 & $11(64.7)$ & 0.006 & $11(61.1)$ & 0.011 \\
\hline Enteral support & $10(31.2)$ & 0.001 & $6(35.2)$ & 0.003 & $1(5.5)$ & 0.415 \\
\hline PEG & $3(9.4)$ & 0.05 & $2(11.7)$ & 0.022 & $6(33.3)$ & 0.004 \\
\hline
\end{tabular}

*In 3(1.2\%) residents colonized with more than one MDR bacteria

Table 2. Multivariate logistic regression analysis of independent risk factors for MDR bacteria.

\begin{tabular}{lrrr}
\hline \multicolumn{1}{c}{ Risk factors } & p value & Odds Ratio & 95 \% Cl \\
\hline Antibiotic use(Last month) & 0.032 & 2.774 & $1.091-7.055$ \\
Immobility & 0.05 & 3.107 & $1.412-6.836$ \\
Enteral support & 0.012 & 3.194 & $1.287-7.922$ \\
\hline
\end{tabular}

Of the 247 participants, 32 (12.9\%) were colonized with Gram-positive [VRE, methicillinresistant S. aureus (MRSA)] and/or Gram-negative bacteria (ESBL-producing E. coli, ESBL-producing
Klebsiella, carbapenemase-producing Klebsiella). Seventeen (6.9\%) were colonized with only resistant Gram-negative bacteria, and 18 (7.3\%) with only resistant Gram-positive bacteria. 
Table 3. The activity of daily living scale and immobility of residents colonized with MDR.

\begin{tabular}{|c|c|c|c|c|c|}
\hline \multirow[b]{2}{*}{$\begin{array}{l}\text { The colonisation of MDR } \\
\text { bacteria(n) }\end{array}$} & \multirow[b]{2}{*}{ Total (n) } & \multicolumn{3}{|c|}{ The activity of daily living scale(n) } & \multirow[b]{2}{*}{$\begin{array}{r}\text { Immobility } \\
\text { (n) }\end{array}$} \\
\hline & & $1-19$ & $20-29$ & $30-36$ & \\
\hline MDR & 32 * & 1 & 6 & 25 & 19 \\
\hline Gram negative MDR & 17 & 1 & 3 & 13 & 11 \\
\hline ESBL K. pneumonia (KPC) & 3 & - & - & $2(1)$ & $2(1)$ \\
\hline ESBL E. coli & 14 & 1 & 2 & 11 & 9 \\
\hline Gram positive MDR & 18 & - & 3 & 15 & 11 \\
\hline MRSA & 8 & - & 1 & 7 & 5 \\
\hline VRE & 10 & - & 2 & 8 & 6 \\
\hline Gram positive + negative MDR & 3 & & & 3 & 3 \\
\hline MRSA + ESBL E. coli & 1 & - & - & 1 & 1 \\
\hline VRE + ESBL E. coli & 2 & - & - & 2 & 2 \\
\hline
\end{tabular}

\section{Gram-positive resistant bacterial colonizati on} MDR S. aureus was isolated from the nasal and/or axillary swab samples of 75 (30\%) residents. MRSA was detected in $3.2 \%(8 / 247)$ of the participants and $10.6 \%(8 / 75)$ of those with S. aureus colonization. Three of the eight MRSA isolates were from nasal carriers. Ten $(4.1 \%)$ of the nursing home residents were perianal VRE carriers. All of the isolates were identified as Enterococcus faecium and had a vancomycin $\mathrm{MIC}$ level of $\geq 4 \mathrm{mg} / \mathrm{L}$.

\section{Gram-negative resistant bacterial colonizati on} ESBL-producing bacteria were detected in a total of $17(6.9 \%)$ of the nursing home residents. Of these bacteria, 14 (82\%) were identified as E. coli and $3(18 \%)$ as $K$. pneumoniae [ $1(0.4 \%)$ of which was carbapenemase-producing K. pneumoniae].

Colonization with multiple resistant bacteria was detected in three (1.2\%) participants. One $(0.4 \%)$ of these residents was colonized with both MRSA and ESBL-producing E. coli, and 2 (0.8\%) were colonized with ESBL-producing E. coli and VRE.

\section{DISCUSSION}

Although the carriage and spread of MDR microorganisms shows regional variation, it presents an important and growing health concern worldwide (10). The MDR bacterial colonization rate in this study group was $12.9 \%$. Routine surveillance assessing MDR bacterial colonization is not yet practiced in nursing homes in Turkey. Our literature search did not yield any studies investigating both Gram-negative and Gram-positive resistant bacterial colonization in Turkish geriatric care centers. The colonization rate we determined emphasizes that elderly nursing homes in Turkey are reservoirs for MDR bacteria. Colonization rates in our study group were $3.2 \%$ for MRSA, $4.1 \%$ for perianal VRE, and $6.9 \%$ for resistant Enterobacteriaceae which vary according to the species of MDR bacteria. These rates were reported to be $6.2 \%$ for MRSA, $12.2 \%$ for ESBL-E, and 0\% for VRE among 2791 residents of 60 nursing homes in Belgium (11). In Germany, the prevalence of ESBL-positive E. coli was found to be $14.7 \%$ in a study conducted with 156 nursing 
home residents (12). These rates vary according to country and nursing home, emphasize that elderly care homes in our country are reservoirs for MDR bacteria.

Drug-resistant bacterial colonization poses a risk for the development of invasive infection and cross-contamination between people (5). It was previously reported that the rate of co-colonization with multiple MDR gram-negative bacteria was 18.4\% among 152 residents with dementia (13). It has also been emphasized that genetically related MDR gram-negative bacteria colonize multiple residents of the same nursing home (14). Although we could not perform molecular analyses in the present study, co-colonization was detected in $1.2 \%$ of the residents.

\section{Risk factors}

The correlation between MDR bacterial colonization rates and ADL indices (i.e. dependence) among nursing home residents must be taken into account when evaluating risk factors. Statistically significant risk factors for MDR bacterial colonization were antibiotic use in the last month, malignancy, immobility, enteral supplementation, and PEG. When significant risk factors were assessed by multivariate logistic regression analysis, antibiotic use in the last month increased MDR bacterial colonization by 2.7 -fold. In the literature, antibiotic exposure is reported to increase colonization with MDR Gram-negative bacteria by 5.6-fold (13). Studies have shown that using antibiotics affected bowel colonization, and the mean duration of colonization with ESBL-E was 144(41-349) days $(5,12)$. Colonization duration was reported as 126.6 \pm 79.1 days for MRSA and 176 194.1 days for VRE (15). Because we obtained cultures from a single time point, we could not determine duration of colonization. However, our finding that $90.6 \%$ of the colonized residents had lived in the geriatric care unit for more than one year, though statistically nonsignificant, suggests that duration of residence may influence colonization.

Other significant risk factors (diet, ADL score, malignancy) are related to the host characteristics of the nursing home residents. ADL scores of the nursing home residents included both general and instrumental $A D L(7,8,16-18)$. In this study, the colonization rates of MDR bacteria increased 3.1 times with immobility or enteral support. Fifty-one percent of the residents had a total ADL score above 30 , indicating complete dependence, and 33.9\% were immobile. It has been reported in the literature that functional disability promotes colonization with MDR bacteria $(2,6)$. In particular, researchers have stressed that rates of MDR bacterial colonization are 3-fold higher in residents with advanced dementia compared to those without dementia (6). Approximately two-thirds of the immobile patients in our study had dementia, which is consistent with the literature. While urinary and vascular catheters were used by only one resident each in our study, those receiving enteral support and undergoing PEG likely had mucosal barrier disruption, which we believe facilitated MDR bacterial colonization during care.

\section{Skin colonization}

As in the rest of the world, antibiotic resistant Gram-positive bacteria (VRE, MRSA) are a concern Turkey, yet these bacteria are not yet considered an important public health issue, except in small hospital-based epidemics. In the present study, MRSA and VRE rates were below 5\%. MRSA colonization rates in geriatric nursing homes vary between 10\% and 50\% (19, 20). In a 2013 study conducted in the Kahramanmaraş Nursing Home in Turkey, Kireççi et al. (21) reported that 98 residents were screened and the prevalence of nasal MRSA colonization was $40.8 \%$. The MRSA colonization rate in our study was lower than the global average. In our 2006 study, which was conducted in the same long-term care facility, we only investigated nasal and axillary MRSA colonization. In that study, 163 nursing home residents were screened and the rate of colonization with S. aureus was $9.3 \%$, and none of the isolated strains were methicillin-resistant (22). In the present study, 30\% of the 247 nursing home residents were colonized with $S$. aureus and $3.2 \%$ with MRSA. These findings indicate that the 
MRSA colonization rate is increasing in this nursing home over time. However, the overall rate of MRSA colonization was still low compared to those reported in other studies. This may be explained by the fact that despite the residents of this nursing home having a high average age and long life expectancy, they also had a high socioeconomic level, and the unit provides a high standard of medical care with an interdisciplinary team. These data highlight the variability of colonization rates and the need for surveillance in long-term care facilities.

\section{Rectal colonization}

Previous studies have reported intestinal ESBLproducing Enterobacteriaceae colonization rates of $20 \%-56 \%$ in geriatric nursing home residents, whereas the prevalence of VRE colonization was lower, at $4.0 \%-9.6 \%$ (12-15). Valenza et al. determined the prevalence of rectal carriage of ESBL-producing Enterobacteriaceae in a longterm care facility to be $14.7 \%$ (12). Although the prevalence of resistant Gram-negative bacteria in the present study is lower than that in the literature, the rate of VRE colonization is comparable to those reported in other publications. This difference may be attributable to the microbiological properties of VRE and resistant Gram-negative bacteria, to different policies concerning antibiotic use, or to host properties. In our study group, $12.9 \%$ were using antibiotics from different classes, $51 \%$ were completely dependent based on their ADL index, and $33.9 \%$ were immobile.

Apart from resistant bacterial epidemics, there are very limited data about carbapenemase-

\section{REFERENCES}

1. Roca I, Akova M, Baquero F, et al. The global threat of antimicrobial resistance: science for intervention. New Microbes New Infect 2015;6:22-9. (PMID:27257501).

2. Dumyati G, Stone ND, Nace DA, Cmich CJ, Jump $\mathrm{RL}$. Challenges and strategies for prevention of multidrug-resistant organism transmission in nursing homes. Curr Infect Dis Rep 2017;19(4):18. doi: 10.1007/s11908-017-0576-7. (PMID:28382547). producing Enterobacteriaceae colonization in longterm care facilities. Recent studies have reported the carriage rate of asymptomatic carbapenemaseproducing Enterobacteriaceae in hospitals as 1.1\%$13 \%$ (23-24). In a study of nursing home residents, Cunha et al. (24) determined the prevalence of carbapenemase-producing Enterobacteriaceae colonization to be $1.4 \%$. The prevalence in our study was $0.4 \%$, which is rather low.

Because of limited funding for this research, our study has a few limitations. Firstly, we were unable to investigate MDR bacterial colonization in the nursing home staff simultaneously. Secondly, molecular studies could not be performed on the isolated MDR bacterial strains. Finally, we could only conduct the colonization screening once. Therefore, permanent and transient colonization could not be evaluated. However, this was the first study in Turkey that investigated multiple MDR bacteria and will form the basis for further research.

In summary, the rate of colonization with any MDR bacteria was $12.9 \%$ in this group of Turkish nursing home residents. Colonization rates of MDR increased 2.7 times with antibiotic use in the last month and approximately 3.1 times with immobility and enteral support. Risk factors for colonization vary according to the species of resistant bacteria. Therefore, evaluating elderly nursing home residents for risk of MDR bacterial colonization whenever possible and conducting surveillance for MDR bacterial colonization in new residents upon arrival will facilitate the management of infectious complications in residents.

3. Reddy P, Malczynski M, Obias A, et al. Screening for extended-spectrum beta-lactamase-producing Enterobacteriaceae among high risk patients and rates of subsequent bacteremia. Clin Infect Dis 2007;45:846-52. (PMID:17806048).

4. Schwaber MJ, Navon-Venezia S, Kaye KS, Ben-Ami R, Schwartz D, Carmeli Y. Clinical and economic impact of bacteremia with extended- spectrum beta-lactamase-producing Enterobacteriaceae. Antimicrob Agents Chemother 2006;50:1257-62. (PMID:16569837). 
5. Lautenbach E, Patel JB, Bilker WB, Edelstein $\mathrm{PH}$, Fishman NO. Extended-spectrum betalactamase-producing Escherichia coli and Klebsiella pneumoniae: risk factors for infection and impact of resistance on outcomes. Clin Infect Dis 2001;32:116271. (PMID:11283805).

6. Mitchell SL, Shaffer ML, Loeb MB, et al. Infection management and multidrug-resistant organism in nursing home residents with advanced dementia. JAMA Intern Med 2014;174:1660-67. (PMID:25133863).

7. Katz S, Ford AB, Moskowitz RW, et al. Katz Index of activities of daily living, In: A. John Rush, Michael B. First, Deborah Blacker (Eds). Handbook of Psychiatric Measures. American Psychiatric Association, American Psychiatric Publishing, USA 2000, pp 1301.

8. Lawton MP, Brody EM. Lawton Instrumental Activities of Daily Living Scale (Lawton IADL): In: A. John Rush, Michael B. First, Deborah Blacker (Eds). Handbook of Psychiatric Measures. American Psychiatric Association, American Psychiatric Publishing, USA 2000, pp 131-3.

9. Clinical Laboratory Standards Institute. Performance standards for Antimicrobial Susceptibility Testing, $17^{\text {th }}-23 r^{\text {d }}$ supplement M100-S13-M100 S23, Wayne, PA. [Internet] Available from: http://www. facm.ucl.ac.be/intranet/CLSI/CLSI-M100S23susceptibility-testing-2013-no-protection.pdf. Accessed:02.01.2018.

10. Huttner A, Harbarth S, Carlet J, et al. Antimicrobial resistance: a global view from the 2013 World Healthcare-Associated Infections forum. Antimicrob Resist Infect Control 2013;2:31. (PMID:24237856).

11. Jans B, Schoevaerdts D, Huang TD, et al. Epidemiology of multidrug-resistant microorganisms among nursing home residents in Belgium. PLoS One. 2013;8:e64908. (PMID:23738011).

12. Valenza G, Nickel S, Pfeifer $Y$, et al. Prevalence and genetic diversity of extended-spectrum $\beta$-lactamase (ESBL)-producing Escherichia coli in nursing homes in Bavaria, Germany. Vet Microbiol 2017;200:138-41. (PMID:26494113).

13. D'Agata EM, Habtemariam D, Mitchell S. Multidrug-resistant gram-negative bacteria: Interand Intradissemination among nursing homes of residents with advanced dementia. Infect Control Hosp Epidemiol 2015;36(8):930-5. (PMID:25920002).

14. O'Fallon E, Schreiber R, Kandel R, D'Agata EM. Multidrug-resistant gram-negative bacteria at a long-term care facility: assessment of residents, healthcare workers, and inanimate surfaces. Infect Control Hosp Epidemiol. 2009;30(12):1172-9.
(PMID:19835474)

15. Fisch J, Lansing B, Wang $L$, et al. New acquisition of antibiotic-resistant organisms in skilled nursing facilities. J Clin Microbiol 2012;50(5):1696-1703. (PMID:22378900).

16. Katz S, Ford AB, Moskowitz RW, Jackson BA, Jaffe MW. The Index of ADL: a standardized measure of biological and psychosocial function. JAMA 1963;185:914-9. (PMID:14044222).

17. Katz S, Downs TD, Cash HR, Grotz RC. Progress in development of the index of ADL. Gerontologist 1970;10:20-30. (PMID:5420677).

18. Lawton MP, Brody EM. Assessment of older people: self-maintaining and instrumental activities of daily. Gerontologist 1969;9:179-186. (PMID:5349366)

19. Denis O, Jans B, Deplano A, et al. Epidemiology of methicillin-resistant Staphylococcus aureus (MRSA) among residents of nursing homes in Belgium. J Antimicrob Chemother 2009;64:1299-1306. (PMID:19808236).

20. Hogardt M, Proba P, Mischler D, Cuny C, Kempf VA, Heudorf U. Current prevalence of multidrugresistant organisms in long-term care facilities in the Rhine-Main district, Germany, 2013. Euro Surveill. 2015;20(26):21171. (PMID:26159310).

21. Kirecci E, Ozer A, Gul M, Tanis H, Sucaklı MH. Nasal MRSA carriages in nursing home residents. Kocatepe Med J. 2013;14:77-82.

22. Avkan-Oguz V, Sezak N, Yapar N, et al. Nasal and axillar carriage of Staphylococcus aureus patients among elderly population in a nursing home. Clin Microbiol Infect 2006;12(Suppl 4): R2003. [Internet] Available from: http://www. clinicalmicrobiologyandinfection.com/article/S1198743X(15)30007-0/fulltext\#cesec1280. Accessed: 02.01 .2018 .

23. ZhaoZC, XuXH, Liu MB, Wu J, Lin J, LiB. Fecal carriage of carbapenem-resistant Enterobacteriaceae in a Chinese university hospital. Am J Infect Control 2014;42:e61-4. (PMID:24773806).

24. Cunha CB, Kassakian SZ, Chan R, et al. Screening of nursing home residents for colonization with carbapenem-resistant Enterobacteriaceae admitted to acute care hospitals: Incidence and risk factors. Am J Infect Control 2016;44(2):126-30. (PMID:26631643). 